\title{
TOWARDS A BROADER UNDERSTANDING OF SELECTION OF STUDENTS TO TRAIN AS HEALTH CARE PROFESSIONALS
}

\author{
D. Pillay*
}

School of Education

e-mail: pillaygv@ukzn.ac.za

\author{
A. Ross* \\ Department of Family Medicine \\ e-mail: rossa@ukzn.ac.za \\ *University of KwaZulu Natal \\ Durban, South Africa
}

\section{ABSTRACT}

Institutes of Higher Learning (IHL) must train healthcare professionals (HCPs) able to meet priority needs of the population and address health system deficiencies. Concerns about the mismatch between outcome and policy have led many IHL to review their curriculum content and training context. In this article we argue for a broadening of selection criteria when choosing students to train as HCPs. A narrative inquiry drawing on life-history interviews and art-based methods was used to generate data on lived lives as told and experienced by six rural-origin HCPs. Analysis of two narrative vignettes framed as dilemmatic spaces show how personal beliefs and practices inform perspectives that HCPs adopted in their learning and development at $\mathrm{IHL}$, and the transformational practices they enacted. How competing forces were negotiated and positions were taken in committing to become HCPs with the capacity to lead transformation is described. Introducing and using dilemmatic spaces analytically enabled deeper understanding of personal beliefs and priorities that informed the choices made, among the many options available, in everyday situations that are important to consider alongside academic potential in the selection of students to train as HCPs who will lead transformation in health care.

Keywords: dilemmatic spaces, student selection, rural health care delivery

\section{INTRODUCTION}

I do quite a lot of things with the community - when we started at university, no-one was sending their kids to university. But now, people in the community sell their cows to send their kids to university because they are able to see what education can do for their kids. (Interview with France on the 18 January 2013).

Recently I was talking at a rural school just like the school I went to, where children could not communicate in English and where they know nothing about the Central Application Office. When I speak at these schools I start off telling them where I come from ... I start at the beginning, and then go on to tell them about the options. (Interview with Siphamandla on the 20 February 2013). 
The National Development Plan 2013 (Manuel et al. 2013) and Human Resources for Health 2030 (DOH 2011) tasked Institutions of Higher Learning (IHL) with training increasing numbers of Health Care Professionals (HCPs) as a key component of ensuring a 'long and healthy life for all South Africans’ (Manuel et al. 2013). These policy documents highlight the need for IHL to develop training plans to address the needs of all South Africans, including those living in rural and underserved communities.

On completion of training South African HCPs need to be skilled and competent, professional and ethical, and able to meet priority needs of the local population, address health system deficiencies and work in cooperation with other HCPs and stakeholders (HPCSA 2012). In mandating this responsibility to IHL, the National Department of Health has reaffirmed the social obligation of IHL to contribute to social change and direct activities towards addressing priority health needs of communities they are mandated to serve (Frenk et al. 2010).

Although local and international evidence shows that rural origin students are more likely to work as HCPs in rural areas (Versteeg and Couper 2011; Wilson et al. 2009), no South African health science university admission criteria favours rural students and some policies (e.g. the national bench mark exam) disadvantage rural students (Reid and Cakwe 2011). Currently South African training institutions use colour as a proxy to enable the university to meet the transformation agenda while failing to meet their social responsibilities to train for the needs of this country. This is evident in the underrepresentation of rural students in training institutions (Tumbo, Couper and Hugo 2009). In addition, the high drop-out and low throughput rates at IHL (Letseka and Maile 2008; Scott et al. 2013; Spaull 2013), challenges many rural healthcare facilities' experience in recruiting and retaining adequate numbers of HCPs (Crisp and Chen 2014; WHO 2013; Versteeg and Couper 2011), the rising number of malpractice claims (Whitehouse 2013), and doctors' unprofessional behaviour and uncaring attitudes (Naidu 2010; Stones 2011) suggest that current models for selecting and training HCPs are not producing the desired outcome and are misaligned to policy intentions envisioned in the Constitution and national planning documents.

In response, South African universities training HCPs are reviewing curriculum content, context and selection criteria, as these have been shown to influence where health care graduates choose to work (Reid 2011; Tesson, Curran, Pong and Strasser 2005). Deepening our understanding of who we select to become HCPs that are autonomous thinking subjects with the desire for acting in community in underserved rural areas, has potential for rethinking university selection criteria - this is the focus of this article. 


\section{BACKGROUND}

Rural areas are often considered remote and disadvantaged (Chisholm et al. 2005) with many rural district hospitals struggling to find sufficient HCPs willing and able to work in these hospitals (Versteeg 2015). Balfour (Balfour and Moletsane 2008) has however suggested that rural areas should rather be understood as dynamic areas with resources and relationships which are potentially transformative and have a profound impact on an individual's ability to succeed in life. Mangaliso (2001) identified the sense of belonging to and connectedness to others in the community as a strength of rural communities, and Marshall and Case (2010) have suggested that coping strategies learnt in rural communities provide tools to succeed at IHL. We use the perspectives of Balfour and Moletsane (2008) and Marshall and Case (2010) to respond to the research question that drives our argument for a broadening of selection criteria when choosing students to train as HCPs: 'What can we learn from the stories of experiences of practising rural-origin HCPs which can inform and broaden selection criteria?'

In this article we draw on the narratives of France and Siphamandla, two of the six research participants in a larger doctoral project using narrative enquiry, titled 'On being a rural origin health care professional; lives, learning and practice', of going to an IHL and graduating as HCPs. We use dilemmatic spaces as the conceptual and analytical frame to understand what perspectives they adopted in response to situations they faced daily. We believe this offers the potential to deepen our understanding of HCPs' everyday lives and the cultural or symbolic knowledges that is garnered in the rural context, that seems to provide the disposition to succeed. We argue that dilemmas are mediated in and through the specific context, and the individuals physical and psychological demeanour negotiated in this dilemmatic space, are as a result of habits and practices developed over a period of time, which help us to understand a person's attitude towards society.

We show how ethical practices and value choices made within these spaces offer both opportunities and constraints (Fransson and Grannas 2013). Making visible the choices and knowledges they prioritise to inform the positions adopted, may broaden our understanding about who to select into our training programmes as potential HCPs. Finally, we show that individuals like France and Siphamandla are able to see themselves as the main source of transformation, rather than waiting for structural or material change (Allan 2013, 27).

\section{THEORETICAL LENS}

We draw on Honig's idea of dilemmatic spaces (1996) as the conceptual lens to frame our 
understanding. Like Fransson and Grannas (2013), we adopt the stance that HCPs and those who wish to become HCPs may sometimes 'find themselves in situations in which there is often no right way of acting', and only a way of acting for the best. As Veyne $(1997,231)$ observes: 'the self is the new strategic possibility' (Foucault 1984, 343). Observing how rural-origin students respond to everyday dilemmas gives us critical insight in the process of selecting potential HCPs for training.

Like Honig (1996) we argue that dilemmas are an everyday feature of people's lives; they are socially constructed and the effects of relations of power and structural conditions. When people are faced with dilemmas, how they react is relational to the social spaces which are embedded within relations of power and in response to structural conditions. While a number of options present themselves (dilemmatic space), and only one can be chosen, the choice made depends on the perspective or positioning one adopts. This choice, Fransson and Grannas (2013) claim, depends on the individual's values, priorities and knowledge.

We find congruence in also drawing on Foucault's theory of ethics (1984), in which he proposes a view of agency depicting individuals as capable of working on themselves to achieve new kinds of existence. Foucault's concern moves to the self as the main object of care and its capacity for both resistance and transformation when making choices from several options.

Forms of practice from this perspective are not only ethical but also political, social and philosophical (Foucault 1988) and evoke 'the care of what exists and might exist'. Foucault foregrounds that the self is the principal object of care, and a means through which care for others can occur (Allan 2013, 29). Using this frame we want to establish an ethical perspective in our response to student selection and healthcare provisioning in underserved areas in South Africa.

While the temptation is to look for individual resilience, we want to understand and be critical of systemic injustices and material conditions in and through which individuals (particularly those who live and work in rural settings) react and respond to the world around them.

\section{METHODOLOGY}

In his doctoral project, AR the second author, employed a life history-narrative inquiry approach for generating data for the larger study. Drawing on a life-history approach, which is about 'a life' lived and experienced historically, culturally and politically, is an attempt to understand their identity and their actions, located in the rural context (Clandinin 2006). This approach has the potential to focus on selected individuals, and as the storyteller, their personal 
accounts reflect subjective positionalities (Pillay 2003).

Data from six rural-origin HCPs practising in a rural context were generated from unstructured interviews and a range of visual methods (photo-memory, artefact retrieval inquiry and collage inquiry). Guided by the intention to select those who could best understand the issues around the educational experience of rural origin HCPs, provide richness of information, be willing to participate in the research process by sharing their stories, be articulate and able to express themselves (Northcutt and McCoy 2004; Polkinghorne 1995; Terre Blanche, Durrheim and Painter 2006), six rural origin HCPs previously supported by an non-government organization supporting the training of rural origin HCPs, were purposefully chosen (Creswell 2008; Malterud 2001; Seidman 2006).

In addition to the above considerations, to ensure broad representation issues of gender (4 males and 2 females), diversity of qualifications, training institutions and currently working in rural areas informed the selection of participants. The six participants were all HCPs from Umkhanyakude district in northern KZN, 450 km north of Durban. The deprivation index for the district was 4.5 in 2012 which was the second lowest deprivation index in the country (Day, Barron, Massyn, Padarath and English 2012.). Of the six, France is an optometrist currently working for the National Department of Health and Siphamandla is a clinical psychologist working in Mtubatuba, northern KwaZulu Natal, and their stories form the basis of the narratives we draw on in this manuscript.

Ethical approval was obtained from the Social Science Ethics Committee of the University of KwaZulu-Natal in Durban (HSS/1205/ 012D). Written informed consent was obtained from all of the participants prior to the start of the study.

Interviews lasted an average of two to four hours and were conducted over three to four sessions. Participants responded to the following question: 'Tell me about your experience of growing up in a rural area, training as an HCP and returning to work in a rural area as an HCP'. They started by telling A.R. of practices they enacted that offered them moments of agency and pleasure, pain and struggle. He listened as they spoke about everyday experiences which ranged from home and family life to the school site, university and working as an HCP. Understanding the relations between private life and personal responsibility highlighted the complexity and ambiguities of lived experiences, instead of a simplistic, linear, fixed story of academic deficit and disadvantage. Audiotaping was used to capture the telling of the life histories.

Each HCP was also requested to select four photographs and an artefact as part of the faceto-face conversations, and to describe the memories these represented and how they related to 
their personal and professional experiences. The self-selected artefact included, for example, a Mathematics Olympiad trophy, representing a critical moment of a participant's educational journey. Photographs captured agentic moments such as a student leader of the Student Representative Council meeting with top-ranking university officials. Construction and discussion of a collage composed by each participant focused on 'A day in my life as an HCP'.

These different methods encouraged participants to open up new ways of thinking (ButlerKisber and Poldma 2010; Butler-Kisber et al. 2002-2003) of a life 'told and experienced' (Bruner 1984). Six reconstructed stories were composed from the range of research sources, and the 'finalised' story was sent to each participant for them to correct, amend or extend (Terre Blanche, Durrheim and Painter 2006). In this article we draw on two of the six biographical narratives by rural-origin HCPs working in healthcare facilities in rural settings.

\section{FINDINGS}

\section{Vignette One: France Nxumalo}

France's personal history intersects with broader cultural changes; dilemmas he faces and choices he makes reflect a radical shift in his views about education and the social positioning of learners in the family, school and society.

France was born in Mtubatuba in northern KwaZulu-Natal in 1981. His parents separated when he was four and he, his brothers and sister moved with their father to Skemelele, close to the Mozambican border. There his father started a spaza shop and built a primary school so that his children could attend school.

\section{First dilemmatic space: From discouraged learner to student activist}

France struggled to achieve what was required to complete his schooling:

The school environment was not that good ... when it was raining or windy classes couldn't continue .... There were some teachers who were lazy or never came to school or come to school drunk. Our maths teacher knew nothing about geometry, and according to the teacher most of the guys who were in the higher grade class were not higher grade material. When asking the teacher about one maths problem in the study guide he said, 'No, don't worry about that, this is a university level maths problems, it's not at your level'. But guess what, when the exam came, the same problem was there!

I was really angry and had a big fight with the teachers to push them to offer maths and science on higher grade. On a number of occasions we engaged the teacher, and if nothing changed we reported to the Principal that these are some of the challenges that we're having. 
Teachers' entitlement is seen as perpetuating the hegemonic pattern of authority and expectation of respect (Bhana 2013) and deference from learners. While such situations are ever-present in rural settings (Chisholm et al. 2005, 25), they are rarely challenged and usually accepted as the norm.

However, France and his friends chose to respond to this situation as a dilemma where choices could be made and their unhappiness voiced. We see conflicting forces at work, and in this negotiating and positioning being a young learner carries little weight. In this way learners like France are faced with a dilemma that makes them uncomfortable (Fransson and Grannas 2012, 7). The search for the 'right thing to do' in relation to the different stakeholders (self, teachers, and principal) is the essence of the dilemma. France's 'turn to ethics' (Allan 2013) informs his decision. Taking responsibility verses being coerced, as a learner he calls for resistance in his struggle for a new kind of existence:

If talking to the teacher and to the headmaster did not work, we would organise a strike to highlight to the community that we can't have a teacher who is not doing his work.

Rather than waiting for a structural or material change, France and his friends see themselves as the main source of transformation and not accepting inferior educational experiences:

We'd call parents to a meeting, we would not go to classes but sit outside and sing and march. We would call the headmaster and indicate that this teacher is doing this and all that and either there's a change of behaviour or the teacher goes and we get another.

Choosing alternative ways to work and observe the school rules, France and his friends revise their relationship with teachers and parents demonstrating belief of self and ability to act with agency (Foucault 1988, 328). Because France cared about what was happening and what might happen, he made ethical and political choices which benefitted him and in turn other students. France passed his matriculation examinations well enough to gain access into university. Becoming a student at a South African university offered him the space for possibilities to perform his success as a rural, African, health science student.

\section{Second dilemmatic space: From silent outsider to authoritative student leader}

The university as a dilemmatic space entails the negotiating of power by students over students and by academic authorities over students. Students from diverse origins (and minority groups) continue to struggle at IHL, creating dilemmas for students like France who feel marginalised and alienated: 
I had to beg the head of department to let me in, because they had finalised admissions ... after a lot of persuasion, they agreed to let me register for a BSc in Optometry. At the beginning ... I remember just sitting and listening in lectures and not uttering any word, not because I could not utter any English, but because the environment was intimidating.

Two values are in tension (Honig 1996), fear as a marginalized and alienated learner and commitment to the self as the principal object of care, inform the choice he makes for himself and the broader student community. From an ethico-political (Foucault 1984, 383) stance, France decides which aspect of the self he needs to work on or change in order to 'do the right thing' as a university learner.

Working within the rules of acceptable behaviour as a university student, France draws on cultural resources to negotiate the situation. His agency is exercised in and through social formations where his power is exercised more productively, working and learning with other students. By mentoring other students and getting involved in student leadership he is able to sustain his commitment to continue and learn - and to become visible and vocal:

I was active in the university mentoring programmes ... when new students came we would take them through registration and assisted them with understanding the university processes, helped them to settle and put them in touch with the tutors and showed them the library and how it's used and all those kinds of things. It was both academic and the university life adjustments. I also made friends at university who helped me adjust in terms of the social life and academically ....

Finding ways to bring about his own learning and transformation in an ethical manner creates possibilities to help others within his circle and within the broader community. Informed by his ethical stance as a black student caring for a different kind of existence for himself and others like him, in a university setting culturally misaligned to the values he and his rural-origin peers bring with them (Stephens et al. 2012, 123), France operates creatively within the university rules:

In 2000 I was elected to the Executive of House Committee which meant speaking to students in English and addressing their issues, so I grew in confidence.

From this position as a student leader he could watch university staff from a more resistant place, and in that way expose the university and staff to a more public gaze (Hope 2013).

France is thus able to resist the dominant traditional hierarchies as an African student operating inside and outside the lectures halls of the university, and to strategise in a controlled and self-regulated way the means and methods to develop voice. He did this within the context of caring and close relationships that he formed along the way as a school learner, university mentor, student leader and successful student: 
The lecturer asked what had happened, because when I came to the department I was this shy boy but all of a sudden in clinics and in class I was now able to contribute.

\section{Third dilemmatic space: Moving into rural health care}

After graduating as an optometrist France returned to his childhood community to work as an HCP. This ethico-political choice is framed by general resistance to the stasis that defines rural healthcare provisioning. Despite being the first to graduate from his community, the hospital was unprepared for him:

When I graduated there were no optometry posts - I eventually started work in an oral hygienist post. The biggest challenge, apart from the money, was working in a system that was dysfunctional.

France did not accept the status quo, nor choose to opt out and leave. In returning he makes a journey towards complete self-mastery - highlighting the moral aspect of his transformation of self (Allan 2013):

Graduation brought a belief that I could do things. I made it my responsibility to ensure that eye services were a priority, not just in my hospital but in the whole district and the province. That led to the creation of two optometry posts per district. It was my job to make sure that we place optometrists and other eye-health professionals in rural areas where people still do not have access to optometry services.

Despite being newly graduated, France provides an alternate version to the dominant discourse that homogenises HCPs' work. As a visionary and architect of change, he recognised and responded to this dilemma, and was able to motivate for posts and build an optometry service throughout the province.

Frances' ability to redefine himself and his potential to open up and engage in ongoing redefinition is the mark of a transformational leader and activist:

I do quite a lot of things with the community - when we started at university, no-one was sending their kids to university. But now, people in the community sell their cows to send their kids to university because they are able to see what education can do for their kids.

His capacity as a ground-breaker, initiator and activist, as a school learner and a university student, through big and small dilemmas he faced in everyday life, speaks to his potential as a leader in healthcare provisioning within rural communities.

Frenk et al. (2010) speaks of the need to train HCPs for the 21st century, HCPs who can strengthen health systems and who can look at a situation and see the potential for 
(transformational) change. Finding, training and supporting such individuals should be a core role of universities committed to fulfilling their mandate of improving health care to individuals and underserved communities.

\section{Vignette Two: Siphamandla Mngomezulu}

Siphamandla was born in rural Ingwavuma in northern KwaZulu-Natal in 1984; his father left to work on the mines in Johannesburg when Siphamandla was four years old. His father never returned home, which left his mother burdened with the responsibility of bringing up Siphamandla and his sister in a fragile family structure particular to African townships and rural contexts (Bhana 2013, 119). These sites were engineered by apartheid to keep African people separate, economically impoverished and powerless (Chisholm et al. 2005; Garran 1908).

Siphamandla remembered his life as a young child:

My mother bought and sold sugar and bananas to generate an income. After she was mugged she stopped getting sugar from Swaziland. The community then recommended her as a community health worker (CHW) as she now had no way of providing for us. As a CHW she earned R400 a month which she supplemented by selling bananas. My mum made R360/ month from the banana business and used this money to pay school fees and to buy something valuable for the family.

Even though men still hold economic power (Bhana 2013), many rural households are supported financially by women. In the rural community where Siphamandla grew up most young men only attended school until Grade 5 (end of primary school), and then left the community to look for work on the mines (Sender 2002). From an early age Siphamandla was expected to fill the 'man's role' around the house in the absence of his father (Bhana 2013). While he recognises that he cannot gain much freedom from the limits of his rural life, he sees moments of hope and space for otherness in the limits of being a mineworker - what Foucault regards as a form of non-positive affirmation $(1977,34)$ :

All I knew was that working on the mines was going to be a great experience, because I could buy some clothes and things to relieve my mom.

However despite the seduction of becoming a worker and accessing a different life for himself and his mother, Siphamandla chose to continue schooling in Ingwavuma.

\section{First dilemmatic space: From poor and inferior learner to top student}

Apartheid's policy of unequal education resulted in serious neglect of rural schools (Chisholm et al. 2005, vii). Being a child of the 1980s Siphamandla received an education designed 
specifically for poor African people:

In Grade 8, I attended Nqobizazi Secondary which was a new school in walking distance from home. We were the first 16 students and that's where I experienced the hardship of being a rural student. Initially we didn't have teachers - so they borrowed two teachers from the primary school to teach us. We didn't have books - the teachers came with about seven books. The school only had two classrooms and there were absolutely no resources, no water, no electricity, nothing.

Despite these structural and material constraints relational to rural schooling practices, Siphamandla recognises that alternate choices are possible for himself and others. Encouraged by his mother he shows initiative and agency, driven by the desire to be a different rural learner. He engages in practices with others that go beyond the school and draws on relations where there is a sense of belonging and connectedness (Mangaliso 2001):

The parents paid money towards building a new classroom and on Fridays we went with a truck to fetch sand from the river and helped build the new classroom. We were 16 very committed students determined to take charge of our own destiny. We took the responsibility of learning on ourselves and competed with one another, which was very important for me as I didn't want my friends to get higher marks than me.

Working closely with others they were able to spur one another on as they coached and mentored one another in the absence of professional teaching resources.

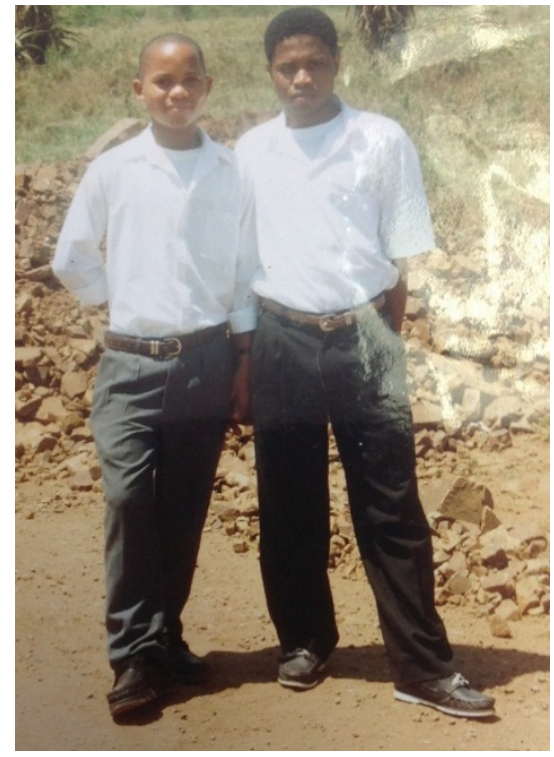

Figure 1: Siphamandla (left) and his friend at Nqobizazi, at the construction site of the new classroom.

Unable to complete his schooling at Nqobizazi Intermediate School Siphamandla moved to Ingwavuma High School for the last two years of his schooling: 
From Grade 11 I went to Ingwavuma High School about $25 \mathrm{~km}$ from home because Nqobizazi didn't have the infrastructure for us to continue. Initially I struggled to adjust at Ingwavuma High, not with academic stuff, but mostly to the social life. Everybody in my class at Ingwavuma High was talking about YizoYizo, the gangster story on TV. I had nothing to contribute to those discussions. I felt so inferior. The kids teased me and called me 'Nqobizazi', which meant that you were from the underprivileged school where people are just joking or clowning around ...

I had to do something to compensate for that and to make me superior. That one thing was to work hard and really excel. Initially I didn't even have a friend as I just spent most of my time studying. Eventually I was in the top class, and taught other students maths and biology and agriculture. In Grade 12 there were very few teachers who were motivated to see us passing. We had a fight with the teachers because they said we would fail maths on higher grade and it will lower our overall marks and prevent us from doing anything after school.

Informed by Foucault's theory of ethics, we recognise Siphamandla's fight as an ethicopolitical fight for quality education. We see conflicting forces at work, and in this negotiating and repositioning see how he resorts to his own methods and techniques 'imposed on the self', (Foucault 1985, 29) to respond to the dangers associated with being poor and inferior.

Siphamandla realises that waiting for any substantial material or structural change to disrupt the oppressive, routinised ways of schooling was pointless, and his only way of 'acting for the best' (Honig 1996) was to make the 'self the new strategic possibility' (Veyne 1997, 231) through working hard and fighting with teachers who stood in his way. This search for the right thing to do in relation to different stakeholders (self, teachers, other learners) who choose to construct poor learners as weak and those who 'would fail maths on higher grade' is the essence of the dilemma. Unable to leave and access better schooling elsewhere and refusing to accept the situation as 'just the way it is', he engages with his struggle for a new kind of existence as a rural learner in a measured and organised manner:

My friend and I wanted to do horticulture and realised we needed to do well in biology and maths, so we arranged evening classes and organised a teacher from a neighbouring school to teach us, because our matric maths teacher got sick in February and never came back. I chose to do all my subjects on higher grade except Afrikaans.

Siphamandlas response is one of determination, recognising education as key to further opportunity (Chisholm et al. 2005, 103)

From June 2001 we knocked off at Ingwavuma High at 14.00 and we attended a maths lesson at SceloSethu. We'd walk there and sit in the maths class as they had a very good teacher. In August 2001 we got a teacher from Nyamane High School to come and teach us maths, but he didn't have a car. We decided to walk to his place [about $10 \mathrm{~km}$ ] after school. We just had to push. In September we started going three or four times a week for those extra maths lessons.

His demonstrates his agency and care of self (Foucault 1988, 328) in refusing to accept an 
education that produces barely literate and numerate learners (Bloch 2009) and highlights the tension between motivated learner and unmotivated teachers.

What kept me going was the sacrifice that my mom made. Only two of us [out of a class of 70 students] wrote matric maths on higher grade, and when the results came back I got B and my friend got $\mathrm{D}$. The teachers were all surprised, and even up to today they are still shocked that we really achieved so much.

In this dilemmatic space negotiating between his mother, uncommitted teachers and motivated learners, we see how Siphamandla is positioned and positions himself in relation to the forces at work. His choice is informed by inner motivation and determination to move from being a poor outsider with poor educational opportunities to a different mode of being (Foucault 1985, 30), seeking alternative ways to be seen and experienced (Hope 2013).

Determined to throw off familiar ways he 'evoke(s) care of what exists and might exist' (Foucault 1988), and seeks out ways to foreground the most important object of care, 'his determined motivated self' - and caring for himself opens up possibilities for the care of others - his mother. Siphamandla obtained a matric exemption in 2002.

\section{Second dilemmatic space: From demotivated matriculant to top university student}

Many schools in rural settings in South Africa produce students with limited chances of obtaining a meaningful education and life after matriculation, due to poverty and poor-quality education (Chisholm et al. 2005, 2). We see here how particular discourses control and normalise life for young men like Siphamandla, and how black people watch themselves to remind themselves what and how they should be. However, Siphamandla negotiates and repositions himself as having initiative, agency and determination:

It was a very difficult time for me between December 2002 and January 2003. I was not getting the sponsorships I was looking for. I remember thinking 'Am I just going to finish matric with that energy and then just stay home like others who were just sitting around Ingwavuma?' Those guys would tell me 'We've been there, don't push it hard, because we know how it feels and we know that it's not possible'. I was very anxious and thought 'Am I going through the same cycle?' University was only if you were rich and your father was owning a tavern, or a shop and have cows.

Siphamandla decides that he needs do something, even if it means engaging in voluntary work, to be seen and known as different - someone with initiative. This ethical stance and choice marks him as different to 'those guys': 
In December and January I did voluntary work at Ingwavuma Orphan Care where I kept meeting new people and hoped that somebody would be able to help me with the university registration fees.

In February 2003 he received financial support from a non-governmental organisation working in Ingwavuma and was accepted to study Psychology at the University of Zululand on the basis of his matric marks. At university he imposed a strict routine of work, sleep and prayer. Despite this he struggled to adjust to the demands of university, and after failing a number of assignments began to question his ability to cope:

I worked so hard when I got to university. It was going to the library, going to the dining hall, or going to church. In the morning and the afternoon I was going to church to pray and that's what kept me really focused. Nothing else mattered to me. Despite working as hard as possible, things just seemed impossible for me.

Siphamandla struggles with the university teaching and learning and he tries hard 'to be faithful' (Foucault 1985, 26) as a student (going to church, the library and dining hall). Positioning himself as a committed and hardworking student and at the same time being positioned as a struggling first-year university student who needs to 'go and see the lecturer' entailed negotiation of power and powerlessness:

In philosophy they would tell you all these Russian stories and you had to give your own critical and creative interpretation of those stories, to think out of your head. With my poor English, it was complicated and on three occasions I got a note on my assignment 'go and see the lecturer'. That was tough because at high school I was always a top student. I started to question myself, 'is there something wrong with me? Is this really for me?'

Siphamandla was determined not only to bring himself into compliance with the university ethos and academic success but to transform in a way that makes him an 'ethical subject' (Foucault 1985, 26). Determined to succeed, in a moment of hope or what Butler $(2004,2)$ calls the 'improvisation within the scene of constraint', we see how and what he does to resist:

I sat with the Professor and tried to understand what was happening. The Professor told me that my ideas were very good but the way I presented them and the way I constructed sentences was not good. The Professor offered for the Department to pay for me to attend English classes - after two weeks I had an idea about how to write at university. By the end of my second year I was selected as the best performer within the Faculty of Arts out of more than 7000 students.

At university individual studying and independence are privileged, despite studies pointing to the value of group study and interdependence (Stephens, Fryberg, Markus, Johnson and Covarrubias 2012). However, for Siphamandla his option is informed by his morality - his deep 
sense of belonging and connectedness with friends:

I had a group of five friends who competed with each other, which really helped me. It was the most amazing and rewarding time; when you compete, you get good marks, and at the end of the day you stay being the top student - that motivated me a lot.

As a team member Siphamandla recognises expertise which can be shared; he was imaginative and creative in drawing on resources that that were not particularly encouraged at university but known to work for him from his experiences as a rural learner. We learn about Siphamandla's loyalty in the journey towards complete self-transformation. This measured and honest movement from invisible, struggling rural student to top university student is attainment of the ultimate goal towards being immersed into the world (Blacker 1998).

\section{Third dilemmatic space: Moving into a rural district hospital as an HCP}

After graduating as a clinical psychologist Siphamandla was approached by BMW with a lucrative deal. This new dilemma involved whether to stay in Johannesburg or return to work in a rural area:

I had this thing that if I took any of these options I would be leaving my family by staying in Jo'burg. So I left all that, and I put in an application for a community service post and started at Hlabisa Hospital ${ }^{1}$ in 2010.

Siphamadla's choice to return to his rural village with an increased understanding of his own context and prevailing conditions positions him differently. As the first clinical psychologist at the rural district hospital close to home he has control over what he can do to change and influence:

I was the first psychologist to work at the hospital and I had to think wider and more strategic than just providing services there. In 2011 I started rotating around the other hospitals in the district and then motivated for each hospital to employ their own clinical psychologist.

Within these spaces are disrupting moments which account for better and more relevant healthcare practices:

There's so much that needs to be done, and I'm getting a better understanding of culturally relevant psychology. There isn't a direct word for depression in Zulu. Ngipathekekabi is the word that signifies that I am depressed, but few patients actually say that at the hospital. People don't realise that they are depressed. Professionally I have come to understand that what the DSM IV says is not what works. The criteria might be the same, but it is the contextual criteria that count. 
In this professional space he becomes known as a ground-breaker, developing a culturally appropriate descriptor for psychological problems in his rural community.

Siphamandla’s determination to lead transformation goes beyond healthcare provisioning and he continues to play a key role in his community:

Since being back at Hlabisa I have been involved in a lot of organisations that do career guidance. At church they invited me to the youth services to motivate the young people, and to talk about growing up in rural areas, and the fact that you can actually succeed.

Recently when I was talking at a school I realised how privileged I was. The school was just like the school I went to where children could not communicate in English and where they know nothing about the Central Application Office. I'm trying to be a role-model and someone that can encourage them. When I speak at schools I start off telling them where I come from ... I start at the beginning, and then go on to tell them about the options.

Siphamandla's determination 'to achieve new kinds of existence' (Allan 2013, 27) and the measured and honest ways in which he works this out with those with whom he shares a deep sense of connectedness arose from his care of the self, and his capacity for both resistance and transformation of traditional hierarchies at work, in schools, at university, in health care and in the broader community.

\section{DISCUSSION}

Dilemmatic spaces for understanding 'how to be' and 'how to act' in becoming and being an HCP

\section{'How to be'}

The two vignettes analysed allow deeper understanding of the complexity of educational contexts inside and outside rural spaces, and how both France and Siphamandla 'react to' and 'react in relation to' them (Honig 1996). Analysis of dilemmatic spaces makes visible competing 'pull and push' forces and options which are valued and positioned in relation to one another when making a choice. The potential that these competing forces open up is critical for understanding which values and priorities inform the ongoing relational processes of negotiation and positioning that France and Siphamandla take up in constituting themselves as ethical subjects capable of working on themselves to 'challenge closed thinking and opening up to the possibility of new forms of thought and action' (Falzon 1998, 91).

Foucault's theory of ethics and ethical practice sharpens our understanding of the particular meanings of self that France and Siphamandla adopt to 'seek out difference, and ... unsettle habitual thinking and prevailing categories' (Falzon 1998, 91), and transform what it 
means to be, know and live as rural HCPs. Their choices to act on themselves are evoked by care of what exists and might exist in emergence of better ways of knowing and being (Foucault 1988, 328).

Honig (1996, 259) explains that dilemmatic spaces 'both constitute and form the terrain of our existence'. Our insight into the dynamic nature of dilemmatic spaces represented through selected moments and the choices made on 'how to be' (personal), 'how to act' (social) and 'how to understand' (professional) (Beauchamp and Thomas 2009, 178) emerge in a space between dilemmas. Being African, male and rural means both France and Siphamandla had to resist particular institutionalising practices which normalise deficit and failure, and exercise agency and responsibility - which they knew was the right thing to do.

\section{'How to act' as learner and student}

Actively effecting transformation of the self, we learn, may be practised silently in measured and regulated ways, or more explicitly through public forums and networking. Through selected dilemmatic spaces we make sense of France and Siphamandla's desire to be 'a different kind of rural learner' relational to particular structural and material constraints. The decisions they take highlight the moral aspect of their self-transformation - revising their modes of being through methods and techniques (working collectively and collaboratively, that were acceptable to and for the care of others.

The vignettes show how the personal is inextricably linked to the professional. Both resist the individualism and independence of university culture, choosing instead connectedness with others. Organically formed, these relations and practices sustain and nourish them (Stephens et al. 2012), and offer them different ways to observe and work with the rules of the educational setting (Allan 2013, 29). The ethical practices which inform their work and life as HCPs are also political, social and philosophical endeavours (Allan 2013, 29).

As transformational leaders in rural health care, France and Siphamandla are able to take responsibility for leading and initiating better healthcare provisioning in the healthcare sector.

\section{How to understand the 'how to be' and 'how to act' in selecting rural-origin students for university study}

The vignettes provide evidence that both France and Siphamandla showed leadership ability prior to entering university, and continued to do so at university. Broadening selection criteria to include rural origin has been accepted as an important strategy to increase the number of HCPs choosing to work in rural areas (Wilson et al. 2009; Stagg 2013). We argue that selection 
criteria that exclude knowledge about the personal (how to be and how to act) is limiting and dangerous. Illuminated in the vignettes and dilemmatic spaces are values and priorities pointing to the potential for becoming transformational leaders in health care, especially in underserved areas.

\section{CONCLUSION}

Drawing from the analysis of lived experience using dilemmatic spaces as the framework - we propose that selecting potential (healthcare) students as future transformational HCPs/leaders requires positioning the individual in a selection 'model' or framework that addresses both personal and social issues by looking inward ('How to be') and outward ('How to act') in relation to the temporal (i.e. the educational event) in terms of its past and its future (Mara 2009). Selecting potential health science students according to this two-dimensional spatial understanding (past and future) will include asking questions and eliciting 'stories' of educational events/dilemmas and deriving interpretations of educational dilemmas, choices and decisions.

Considering the individual's internal (values-reactions-ethical dispositions) and external forces (initiatives-ethical practices) relational to particular educational dilemmas/events - past and future - we conclude, is inextricably linked to the choices and decisions they make as transformational HCPs.

In light of policy prerogatives for training transformational leaders and increasing the number of graduates choosing to work in under-resourced areas, selection criteria that include and go beyond academic ability and experience are critical.

\section{NOTE}

1 Hlabisa Hospital is a district hospital in Northern KwaZulu Natal

\section{REFERENCES}

Allan, J. 2013. Foucault and his acolytes: Discourse, power and ethics. In Social theory and education research: Understanding Foucault, Habermas, Bourdieu and Derrida, ed. M. Murphy, 21-34. London and New York: Routledge.

Balfour, R. M. and R. Moletsane. 2008. Troubling contexts: Towards a generative theory of rurality as education research. Journal of Rural and Community Development 3: 95-107.

Beauchamp, C. and L. Thomas. 2009. Understanding teacher identity: An overview of issues in the literature and implications for teacher education. Cambridge Journal of Education 39(2): 175189.

Bhana, D. 2013. Parental views of morality and sexuality and the implications for South African moral education. Journal of Moral Education 42(1): 114-128. 
Blacker, D. 1998. Intellectuals at work and in power: Towards a Foucauldian research ethic. In Foucault's challenge: Discourse knowledge and power in education, ed. T. S. Popkewitz, and M. Brennan, 348-367. New York: Teachers' College press.

Bloch, G. 2009. The toxic mix: What's wrong with South Africa's schools and how to fix it. Cape Town Tafelberg.

Bruner, E. M. 1984. The opening up of anthropology. In Text, play and story: The construction and reconstruction of self and society, ed. E. M. Bruner, 1-18. Washington DC: The American Ethnological Society.

Butler, J. 2004. Undoing gender. New York: Routledge.

Butler-Kisber, L. and T. Poldma. 2010. The power of visual approaches in qualitative inquiry: The use of collage making and concept mapping in experiential research. Journal of Research Practice 6(2): 1-16.

Butler-Kisber, L., S. Allnutt, L. Furlini, N. Kronish, P. Markus, T. Poldma and M. Steward. 2002- 2003. Insight and voice: Artful analysis in qualitative inquiry. Journal of the Arts and Learning Special Interest Group of the American Education Research Association 19(1): 127.

Chisholm, L., S. Morrow, M. wa Kivilu and K. Engel. 2005. Emerging voices. A report on education in South African rural communities. Cape Town: Human Sciences Research Council.

Clandinin, D. J. 2006. Narrative inquiry: A methodology for studying lived experience. Research Studies in Music Education 27(1): 44-54. doi: 10.1177/1321103x060270010301.

Creswell, J. 2008. Educational research. Planning, conducting and evaluating quantitative and qualitative research. 3rd Ed. New Jersey: Pearson Education.

Crisp, N. and L. Chen. 2014. Global supply of health professionals. New England Journal of Medicine 370(10): 950-957. doi: doi:10.1056/NEJMra1111610

Day, C., P. Barron, N. Massyn, A. Padarath and R. English. 2012. District health barometer 2010/11. Durban: Health systems trust http://www.hst.org.za/publications/district-health-barometer201011 (accessed 16 July 2015).

Department of Health. 2011. Human Resources for health for South Africa 2030. Pretoria: South African National Department of Health.

DOH see Department of Health.

Falzon, C. 1998. Foucault and social dialogue: Beyond fragmentation. London and New York: Routledge.

Foucault, M. 1977. Truth and power. In Power/Knowledge: Selected interviews and other writing 19721977, ed. C. Gorden. Sussex: The Harvester Press.

Foucault, M. 1984. On the genealogy of ethics: An overview of work in progress. In The Foucault Reader, ed. P. Rabinow. New York: Pantheon Books.

Foucault, M. 1985. The use of pleasure: The history of sexuality, 2. Translated by R. Hurley. Harmondsworth: Penguin.

Foucault, M. 1988. On power, politics, philosophy, culture: Interviews and other writings 1977-1984. Translated by Alan Sheridan and others. New York and London: Routledge.

Fransson, G. and J. Grannas. 2013. Dilemmatic spaces in educational contexts - towards a conceptual framework for dilemmas in teachers work. Teachers and Teaching: Theory and Practice 19(1): 4-17. doi.org/10.1080/13540602.2013.744195.

Frenk, J., L. Chen, Z. A. Bhutta, J. Cohen, N. Crisp, T. Evans, ... H. Zurayk. 2010. Health professionals for a new century: Transforming education to strengthen health systems in an interdependent world. The Lancet 376(9756): 1923-1958.

Garran, R. 1908. Sources of revenue. In The government of South Africa, 157-159. Cape Town: Central News Agency.

Health Professions Council of South Africa. 2012. Core competencies for undergraduate students in the 
clinical associate, dentistry and medical teaching and learning programmes in South Africa. Pretoria: Health Professions Council of South Africa.

Honig, B. 1996. Difference, dilemmas, and the politics of home. In Democracy and difference. Contesting the boundaries of the political, ed. S. Benhabib. New Jersey: Princeton University Press.

Hope, A. 2013. Foucault, panopticism and school surveillance research. In Social theory and education research: Understanding Foucault, Habermas, Bourdieu and Derrida, ed. M. Murphy, 35-51. London and New York: Routledge.

HPCSA see Health Professions Council of South Africa.

Letseka, M., and S. Maile. 2008. High university drop-out rates: A threat to South Africa's future. Policy brief March 2008. Cape Town: Human Sciences Research Council. http://ukzn.worldcat.org/ title/high-university-drop-out-rates-a-threat-to-south-africas-future/oclc/228420037\&referer= _results (accessed 8 November 2015).

Malterud, K. 2001. Qualitative research: Standards, challenges, and guidelines. The Lancet 358(9280): 483-488.

Mangaliso, M. P. 2001. Building competitive advantage from Ubuntu: Management lessons from South Africa. Academy of Management Executive 15(3): 23-33.

Manuel, T. A., C. Ramaphosa, M. Altman, M. Balintulo, H. Coovadia, A. Eberhard, ... K. von Holt. 2013. National Development Plan 2030. Pretoria: South African Government.

Mara, D. 2009. Interviewing texts: Fiction writing as method of inquiry. Assignment submitted to University of Western Ontario. http://www.edu.uwo.ca/Narrative_Inquiry/documents/ Mara,\%202009.pdf (accessed 16 July 2015).

Marshall, D. and J. Case. 2010. Rethinking 'disadvantage' in higher education: A paradigmatic case study using narrative analysis. Studies in Higher Education 35(5): 491-504. doi: 10.1080/03075070903518386.

Naidu, E. 2010. SA's dodgy doctors. IOL news, 28 March 2010. http://www.iol.co.za/news/southafrica/sa-s-dodgy-doctors-1.477714 (accessed 16 July 2015).

Northcutt, N. and D. McCoy. 2004. Interactive qualitative analysis: A systems method for qualitative analysis. California: Sage Publications.

Pillay, G. 2003. Successful teachers. A Cubist narrative of lives, practices and the evaded. PhD thesis, University of KwaZulu Natal. http://researchspace.ukzn.ac.za/xmlui/handle/10413/3135 (accessed 16 July 2015).

Polkinghorne, D. 1995. Narrative configuration in qualitative analysis. In Life history and narrative, ed. J. A. Hatch and R. Wisniewski, 5-23. London: Falmer press.

Reid, S. J. 2011. Pedagogy for rural health. Education for Health (Abingdon) 24(1): 536.

Reid, S. J. and M. Cakwe. 2011. The contribution of South African curricula to prepare health professionals for working in rural or under-served areas in South Africa: A peer review evaluation. South African Medical Journal 101: 34-38.

Scott, I., N. Ndebele, N. Badsha, B. Figaji, W. Gevers and B. Pityana. 2013. A proposal for undergraduate curriculum reform in South Africa: The case for a flexible curriculum structure. Pretoria: Council on Higher Education.

Seidman, I. 2006. Interviewing as qualitative research: A guide for researchers in education and the social sciences. 3rd Ed. New York: Teachers College press.

Sender, J. 2002. Women's struggle to escape rural poverty in South Africa. Journal of Agrarian Change 2(1): 1-49. doi:10.1111/1471-0366.00023.

Spaull, N. 2013. South Africa's education crisis: The quality of education in South Africa 1994-2011. Johannesburg: Centre for Development and Enterprise.

Stephens, N. M., S. A. Fryberg, H. R. Markus, C. S. Johnson and R. Covarrubias. 2012. Unseen 
disadvantage: How American universities' focus on independence undermines the academic performance of first-generation college students. Journal of Personality and Social Psychology 102(6): 1178-1197. doi:10.1037/a0027143.

Stones, L. 2011. Conduct unbecoming. The Bulletin 1: 41. http://www.hpcsa.co.za/Uploads/editor/ UserFiles/downloads/publications/bulletin/hpcsa_bulletin.pdf (accessed 13 February 2015).

Terre Blanche, M., K. Durrheim and D. Painter, (eds.). 2006. Research in practice. Applied methods for the social sciences. Cape Town: University of Cape Town.

Tesson, G., V. Curran, R. Pong and R. Strasser. 2005. Advances in rural medical education in three countries: Canada, the United States and Australia. Educ Health (Abingdon) 18(3): 405-415. doi:10.1080/13576280500289728.

Tumbo, J. M., I. D. Couper and J. F. Hugo. 2009. Rural-origin health science students at South African universities. South African Medical Journal 99(1): 54-56.

Veyne, P. 1997. The final Foucault and his critics. In Foucault and his interlocutors, ed. E. Davidson, 225-233. Chicago: University of Chicago Press.

Versteeg, M. 2015. Rural health fact sheet 2015. http://www.rhap.org.za/wp-content/uploads/ 2015/09/RHAP-Rural-Health-Fact-Sheet-2015-web.pdf (accessed 16 July 2015).

Versteeg, M. and I. D. Couper. 2011. Position paper: Rural health - Key to a healthy nation. http://www.rhap.org.za/wp-content/uploads/2011/03/Rural-Health-Key-to-a-Healthy-NationRHAP-Position-Paper_March-2011.pdf (accessed 16 July 2015).

Whitehouse, S. 2013. Counting the cost of GP claims. Practice Matters 1(1): 1-8. http://www.medicalprotection.org/docs/default-source/pdfs/sa-practice-matters-pdfs/jul-2013. pdf?sfvrsn=2 (accessed 16 July 2015).

WHO see World Health Organization.

Wilson, N. W., I. D. Couper, E. de Vries, S. Reid, T. Fish and B. J. Marais. 2009. A critical review of interventions to redress the inequitable distribution of healthcare professionals to rural and remote areas. Rural Remote Health 9(2): 1060. doi:1060 [pii].

World Health Organization. 2013. A universal truth: No health without a workforce. http://www.who.int/workforcealliance/knowledge/resources/ hrhreport2013/en/ (accessed 16 July 2015). 